\title{
KEBERKESANAN KAEDAH PENGAJARAN BERSAMA DALAM MENINGKATKAN PENCAPAIAN PENULISAN KARANGAN MURID TINGKATAN 4
}

\author{
The Effectiveness of Coaching Teaching Methods in Improving Writing \\ Achievement of Form 4 Students
}

\author{
Nor Azimah Ariffin \\ embuns88@gmail.com \\ Dahlia Janan \\ dahlia@fbk.upsi.edu.my \\ SMK Hamid Khan, Tapah, Perak \\ Universiti Pendidikan Sultan Idris
}

\begin{abstract}
ABSTRAK
Kaedah pengajaran yang berbeza memberi kesan yang berbeza kepada pelajar. Oleh yang demikian, kajian ini meneliti kesan penggunaan kaedah pengajaran bersama dalam pengajaran dan pembelajaran karangan terhadap murid tingkatan empat. Kaedah pengajaran bersama merupakan kaedah yang dijalankan secara bersama, iaitu dua atau lebih pendidik bekerja dengan kumpulan pelajar yang heterogen di dalam bilik darjah pada masa yang sama. Reka bentuk kajian ini menggunakan kuasi eksperimen yang melibatkan kaedah konvensional bagi kumpulan kawalan dan kaedah pengajaran bersama bagi kumpulan rawatan. Dalam kumpulan rawatan sebanyak tujuh daripada 12 elemen yang terkandung dalam kaedah pengajaran bersama ini akan digabungjalinkan sebagai asas kajian untuk melihat kesan kaedah pengajaran bersama terhadap pencapaian murid. Data pencapaian murid dikumpulkan dengan menggunakan ujian pra dan ujian pasca. Pemilihan sampel pula dibuat secara rawak iaitu, seramai 25 orang murid tingkatan empat telah dipilih sebagai sampel untuk kumpulan rawatan dan 25 orang murid bagi kumpulan kawalan. Dapatan kajian ini menunjukkan terdapat perbezaan markah ujian Pasca antara kumpulan rawatan dan kumpulan kawalan. Selain itu, perbezaan ini juga menunjukkan peningkatan markah kumpulan rawatan yang menjalani kaedah pengajaran bersama lebih baik daripada kumpulan kawalan. Implikasi kajian ini memberikan murid dan guru ruang menggunakan kaedah pengajaran karangan yang lebih berkesan bagi mencapai objektif yang diingini.
\end{abstract}

Kata kunci: pengajaran bersama; karangan; murid; keberkesanan

\begin{abstract}
Different teaching methods have different effects on students. Therefore, this study examines the effect of the use of co-teaching methods in the teaching and learning of essays of form four students. A co-teaching method is a jointly conducted method whereby two or more educators work with a heterogeneous group of students in the classroom at the same time. The design of this study uses quasi experiments where two different teaching methods are implemented in the teaching and learning process, namely conventional methods for control groups and co-teaching methods for treatment groups. In the treatment group, seven of the 12 elements contained in this method of coteaching will be incorporated as the basis of the study to see the effect of the method on the achievement of the students. Pupil performance data is collected using pretest and posttest. Sample selection was randomized, of which 25 form four students were selected as samples for the treatment group and 25 pupils for the control group. The findings show that there are differences in post-treatment test scores between treatment groups and control groups. Additionally, these differences also show an increase in the treatment group score that undergo a better teaching method than the control group. The implication of this study gives pupils and classroom teachers a more effective teaching method to achieve the desired objectives
\end{abstract}

Keywords: coaching; essay; pupils; effectiveness 


\section{PENGENALAN}

Penulisan karangan merupakan salah satu elemen yang terkandung dalam sukatan pelajaran bagi mata pelajaran Bahasa Melayu (BM). Melalui penulisan karangan yang dihasilkan oleh pelajar, guru dapat mengetahui dan menilai sejauh manakah tahap penguasaan bahasa seseorang pelajar. Tuan Jah Tuan Yusof dan Faridah Nazir (2011) menerangkan bahawa mengarang merupakan satu kemahiran yang perlu dipelajari dan dilatih serta dikuasai oleh setiap murid kerana sebahagian besar dalam pendidikan formal memerlukan aktiviti menulis dan mengarang sebagai kaedah untuk menyampaikan maklumat, idea dan pendapat. Oleh hal yang demikian, aktiviti membina sebuah karangan bukan sahaja bertujuan untuk melihat hasil karangan, malah lebih kepada bagaimana proses mengarang itu dilakukan supaya dapat diaplikasikan bukan sahaja dalam pembelajaran Bahasa Melayu, tetapi juga dalam mata pelajaran yang lain. Rentetan daripada pemasalahan kelemahan pelajar membina karangan telah mengakibatkan pencapaian pelajar dalam peperiksaan Bahasa Melayu khususnya turut terjejas. Laporan Lembaga Peperiksaan (2010) dalam Shahlan Surat et.al (2013) menyatakan bahawa bilangan murid yang berpencapaian sederhana dalam penulisan karangan adalah lebih banyak daripada yang berpencapaian tinggi (cemerlang) dan rendah. Hal ini menunjukkan bahawa penggunaan pelbagai kaedah masih lagi tidak dapat melonjakkan pencapaian murid ke tahap yang lebih cemerlang. Oleh itu, mengenal pasti pendekatan yang berupaya untuk mengubah pencapaian murid adalah penting disamping melihat kemampuan dan kebolehan guru untuk melaksanakan yang terbaik demi menaikkan prestasi murid dalam penulisan karangan.

Pengajaran bersama dalam kajian ini dapat lebih difahami daripada pandangan dan kajian daripada penulis-penulis yang terdahulu. Villa et.al (2004) mentakrifkan bahawa pengajaran bersama adalah apabila dua atau lebih orang berkongsi tanggungjawab untuk mengajar sebilangan atau semua pelajar di dalam sebuah kelas. Selain itu, pengajaran bersama juga didefinisikan sebagai pengajaran kolaboratif yang melibatkan dua atau lebih pendidik yang mengajar murid yang heterogen. Berdasarkan definisi yang telah diberikan kedua-dua penulis bersetuju bahawa pengajaran bersama berlangsung dengan gabungan tanggungjawab antara dua orang guru atau lebih yang mengajar murid dalam pelbagai bidang. Pengajaran bersama ini akan berkesan kerana setiap guru mempunyai kekuatan dan kelemahan yang tersendiri, maka melalui kaedah pengajaran bersama murid-murid bertuah kerana dapat menerima pengajaran dua orang guru yang saling melengkapi (Goldwriter dalam Neas, 2012).

Sehubungan dengan itu, pengajaran bersama yang berlangsung dalam kajian ini ialah pengajaran yang melibatkan dua orang guru yang mengajar di dalam sebuah kelas yang sama. Kajian ini akan menggunakan soalan karangan sebagai instrumen kajian dan data yang akan dianalisis sebagai dapatan kajian ialah markah karangan murid.

\section{TUJUAN KAJIAN}

Kajian yang dijalankan ini bertujuan mencadangkan sebuah kaedah pengajaran karangan yang boleh diaplikasikan oleh guru-guru di dalam kelas sebagai penyelesaian kepada kaedah tradisional yang masih tidak dapat meningkatkan pencapaian murid dalam penulisan karangan. Kajian ini selanjutnya dapat dijadikan sebagai alternatif kaedah pengajaran yang boleh digunakan untuk murid yang pelbagai di dalam sesebuah kelas.

\section{OBJEKTIF KAJIAN}

1. Mengenal pasti kesan penggunaan kaedah pengajaran bersama terhadap pencapaian murid dalam penulisan karangan Bahasa Melayu.

\section{HIPOTESIS KAJIAN}

1. Ho1- Tidak terdapat perbezaan bagi skor min pencapaian murid dalam ujian pra antara kumpulan rawatan dengan murid kumpulan kawalan.

2. Ho2- Tidak terdapat perbezaan bagi skor min pencapaian pelajar dalam ujian pasca 
antara murid kumpulan rawatan dengan murid kumpulan kawalan.

\section{KAJIAN- KAJIAN BERKAITAN CO-TEACHING}

Pengajaran bersama bagi para pengkaji barat bukanlah sesuatu yang baru, sebaliknya ia telah mula dikaji seawal tahun 1900 lagi. Hal ini bermakna, pengajaran bersama telah dulu diaplikasi dan digunakan sebagai salah satu pendekatan dalam proses pengajaran dan pembelajaran dalam pelbagai bidang. Salah satu kajian yang menarik telah dilakukan oleh Parker (2010) yang berjudul "The Impacts of Co-Teaching on The Ganeral Education Student". Dapatan kajian ini menunjukkan bahawa pengajaran bersama hanya berkesan dan menunjukkan perbezaan yang signifikan bagi kelas Matematik dan tiada perbezaan yang signifikan bagi kelas Seni Bahasa. Secara dasarnya, hasil kajian ini telah memberi tahu bahawa pengajaran pengajaran bersama tidak semestinya bersesuaian degan semua mata pelajaran yang mahu diajarkan. Walau bagaimanapun, dalam kajian pengkaji ini tidak pula dinyatakan elemen yang mana satu digunakan untuk menyampaikan pengajaran, sama ada memilih salah satu elemen atau mengaplikasikan kesemua elemen.

Kajian berikutnya yang diambil ialah "Implementing a Co-Teaching Model for Implementing EFL Learners' Grammatical Proficiency" yang dijalankan oleh Mohammad Aliakbari (2009). Kajian ini menghasilkan satu penemuan bahawa pengajaran bersama tidak mampu menunjukkan perbezaan yang signifikan dalam kalangan murid yang belajar tatabahasa. Kajian ini telah dijalankan dengan menggunakan kaedah kuasi eksperimen yang melibatkan 58 orang murid dan dibahagikan kepada dua kumpulan yang ditandai dengan kumpulan rawatan dan kumpulan kawalan. Dapatan kajian ini sekali lagi tidak menyebelahi pengajaran bersama yang dilihat tidak dapat meningkatkan pencapaian murid yang diajar dengan pengajaran bersama, sebaliknya pencapaian hampir sama dengan kumpulan kawalan. Sebagaimana kajian yang dihuraikan sebelum ini, kajian oleh Mohammad Aliakbari ini juga tidak menerangkan penggunaan elemen yang digunakan yang menjadi asas kepada pengajaran tatabahasa berkenaan. Sedangkan pengkaji ini telah mengambil kerangka model pengajaran bersama yang telah menggariskan lima model yang boleh digunakan.

Potter (2011) dalam kajiannya yang bertajuk "Co-Teaching as an Effective Approach to Improving Student Result" ini pula telah dijalankan terhadap murid tahap tiga hingga lima berkeperluan khas yang mempunyai masalah ketidakupayaan dalam pembelajaran seramai 20 orang. Murid dibahagikan kepada kumpulan yang diajar oleh dua orang guru pengajaran bersama manakala sekumpulan lagi diajar oleh seorang guru seperti biasa. Kajian ini tidak menyatakan elemen pengajaran bersama yang mana satu yang diguna pakai dan hanya menyatakan cara pengajaran bersama dijalankan secara ringkas iaitu guru pendidikan khas dan guru biasa bekerjasama untuk mengajar di dalam sebuah kelas. Kajian yang menguji tahap kefahaman membaca murid ini telah menunjukkan peningkatan yang baik bagi kelas yang diajar secara pengajaran bersama berbanding kelas yang diajar seperti biasa dengan seorang guru. Walaupun kajian ini agak berbeza dengan dua kajian di atas, yang mana kajian ini menunjukkan kejayaan penggunaan pengajaran bersama, namun kajian ini juga tidak menyatakan elemen pengajaran bersama yang mana satu digunakan sebagai sandaran kajian.

Melalui kajian-kajian pengajaran bersama yang telah dijalankan ini menunjukkan bahawa pengajaran bersama ini sememangnya sebagai salah satu alternatif yang bersesuaian dengan persekitaran murid masa kini. Kaedah pengajaran bersama ini perlu diguna pakai dalam proses pengajaran dan pembelajaran di Malaysia kerana ia mungkin dapat memudahkan murid belajar dan guru untuk merangka serta melaksanakan sebuah aktiviti pengajaran dan pembelajaran yang lebih berkesan.

\section{KAJIAN- KAJIAN BERKAITAN PENGAJARAN KARANGAN}

Kajian-kajian berkenaan penulisan karangan ini telah banyak dilakukan oleh pengkaji-pengkaji saban masa. Tujuan utama dilaksanakan sesebuah kajian adalah untuk mengenal pasti pemasalahan yang berlaku dan mencari jalan bagi menyelesaikan masalah tersebut. Walau bagaimanapun, kajian berkenaan penulisan karangan dalam kalangan murid ini tidak pernah ketemu noktahnya apabila sering dikaji dan dikaji sehinggalah ke saat ini. Maka, berdasarkan fenomena ini jelas menunjukkan bahawa pemasalahan ini umpama tiada noktahnya dan masalah tetap berlaku walaupun sudah diimplementasikan kaedah baru hasil dapatan kajian yang dilakukan. 
Kajian pertama berkenaan kaedah pengajaran karangan ini adalah yang telah dilakukan oleh Rozita Radhiah Said dan Abdul Rashid Jamian (2012) yang berjudul Amalan Pengajaran Karangan Guru Cemerlang di dalam Bilik Darjah: Kajian Satu Kes Pelbagai Lokasi. Kajian ini telah memperlihatkan beberapa masalah dan kepincangan yang berlaku dalam aktiviti pengajaran dan pembelajaran di dalam kelas. Secara zahirnya apabila dikatakan guru cemerlang pastilah pengajaran yang dilakukan mampu menaikkan prestasi murid namun berdasarkan kajian ini dapatan yang sangat menarik diperoleh ialah pendekatan pengajaran secara trasidional masih lagi mendominasi cara pengajaran guru cemerlang di dalam kelas. Kajian ini dijalankan secara kualitatif dengan data daripada rakaman video, pemerhatian, temu bual dan analisis dokumen berkaitan terhadap lima orang guru cemerlang yang dipilih berdasarkan kaedah persampelan purposif. Dapatan kajian ini menceritakan bahawa salah satu masalah terbesar yang menyebabkan guru cemerlang masih menggunakan kaedah pengajaran berpusatkan guru adalah kerana jumlah bilangan murid di dalam sesebuah bilik darjah yang terlalu ramai. Hal ini ditambah lagi dengan masalah kepelbagaian aras murid di dalam kelas berkenaan. Selain itu, dapatan kajian ini juga menunjukkan guru terpaksa menanggung beban kerja sebagai guru bahasa di samping dengan faktor persediaan guru sebelum memulakan pengajaran. Maka, berdasarkan pemasalah dalam kajian ini, masalah utama bukanlah kepada ilmu dan kepakaran guru sebaliknya ia bergantung kepada tahap kesediaan guru menggunakan segala kemahiran untuk mengajar. Namun kekangan kerja dan kepelbagaian masalah telah membataskan pengaplikasian kaedah yang menarik bagi pengajaran karangan. Kajian ini telah menunjukkan kekangan yang berlaku di pihak guru, namun tidak pula dijelaskan kaedah lain yang harus digunakan bagi mengatasi masalah yang dihadapi.

Kajian berikutnya telah dijalankan oleh Mariam (2011) yang bertajuk Pengajaran Kemahiran Penulisan Karangan Naratif Bahasa Melayu Menggunakan Kaedah Kata Tanya. Kajian ini telah dijalankan terhadap murid-murid tahun lima dengan kaedah kuantitatif menggunakan soal selidik dan penilaian terhadap hasil penulisan. Kajian ini menekankan penggunaan kata tanya untuk meningkatkan prestasi penulisan karangan murid. Berdasarkan reka bentuk kajian ini pengkaji hanya menekankan masalah penulisan karangan dalam kalangan pelajar, namun tidak pula ditekankan berkenaan kekangan dan masalah yang berlaku dalam kalangan guru bagi menyampaikan pengajaran yang terbaik kepada murid. Pengkaji berpendapat, walau sebaik manapun teknik atau model yang digunakan untuk diaplikasikan terhadap pelajar, namun seandainya di pihak guru itu mempunyai kekangan-kekangan tertentu untuk menjayakannya, teknik atau model berkenaan tetap tidak akan dapat meningkatkan pencapaian murid secara holistik.

Kajian bertajuk Aplikasi Pembelajaran Jigsaw II dalam Pengajaran Penulisan Bahasa Melayu yang dilakukan oleh Yusfaiza Yusuff dan Mohd Isha Awang (2012) merupakan sebuah kajian dengan kaedah yang menarik. Kajian ini menggunakan kaedah yang mampu meningkatkan penglibatan murid dalam satu-satu siri proses pengajaran dan pembelajaran itu. Seramai 60 orang responden di tingkatan empat terlibat dalam kajian yang menggunakan kaedah kuasi eksperimen yang bermakna 30 orang dalam kumpulan kawalan, manakala 30 orang lagi dalam kumpulan rawatan. Penelitian terhadap Pembelajaran Jigsaw II ini saling tidak tumpah dengan kaedah pembelajaran Kooperatif yang mana pelajar dibahagikan kepada kumpulan-kumpulan tertentu dan setiap kumpulan mempunyai murid yang pakar dalam sesuatu topik atau kemahiran. Murid akan berbincang dan memahami topik diberikan dalam kumpulan Jigsaw II masing-masing dan akan kembali ke kumpulan asal bagi berkongsi maklumat yang diperoleh. Dapatan kajian ini menunjukkan hasil positif yang mana setelah menggunakan kaedah ini peningkatan pencapaian penulisan karangan bagi kumpulan rawatan telah direkokan. Kajian ini dijalankan rentetan daripada pemasalahan dan kebimbangan pengkaji terhadap pencapaian Bahasa Melayu dan juga kerana kejayaan telah dicatatkan oleh pengkaji terdahulu dengan menggunakan kaedah ini. Apabila diamati, kaedah Jigsaw II ini agak menarik untuk diaplikasikan dan berdasarkan penyataan pengkaji bahawa biarpun murid mempunyai potensi dan kemampuan hebat dari segi kecerdasan namun strategi pengajaran guru kurang berkesan boleh mempengaruhi pencapaian murid dan begitulah sebaliknya. Yusfaiza Yusuff dan Mohd Isha Awang (2012) telah menunjukkan sedikit kelemahan dalam kajian ini berdasarkan penyataan pengkaji sendiri walaupun kajian ini berjaya membuktikan keberkesanan Jigsaw II. Dalam kajian ini, tahap pemikiran dan kemampuan murid yang tinggi sangat diperlukan kerana wujud kumpulan pakar, namun seandainya kaedah ini diaplikasikan terhadap murid berpengetahuan aras rendah di kelas yang lemah pasti akan timbul masalah terhadap penguasaan sesuatu kemahiran berkenaan. Akhirnya, guru itu sendiri yang akan menjadi pakar rujuk berkenaan pelbagai persoalan kerana murid itu tadi sudah nyata 
mempunyai masalah dalam pembelajaran dan tidak mampu membuahkan pemikiran yang bernas dalam masa yang singkat, maka tidak mustahil pembelajaran Jigsaw II ini akan kembali kepada pengamalan pengajaran dan pembelajaran tradisional.

Indah Eyah Abu Samah (2012) membuat sebuah kajian kuasi eksperimen bertajuk Menilai Keberkesanan Teknik Sumbang Saran Terhadap Pencapaian Kemahiran Menulis Karangan Murid Tingkatan Empat yang menggunakan 60 orang sampel, iaitu 30 orang bagi kumpulan kawalan dan 30 orang bagi kumpulan rawatan. Kajian ini sebenarnya dijalankan terhadap murid yang berpencapaian rendah dalam mata pelajaran Bahasa Melayu dan didapati dapatan kajian ini markah dan prestasi kumpulan rawatan telah menunjukkan pencapaian yang memberangsangkan. Kajian ini hanya menggunakan teknik sumbang saran yang menyasarkan dapatan terhadap tiga aspek utama iaitu skor pencapaian murid, skor idea yang relevan dan skor olahan karangan yang menarik. Walaupun kajian ini telah berjaya menunjukkan keberkesanannya dan mencatatkan peningkatan pencapaian penulisan karangan murid kumpulan rawatan, namun reka bentuk proses pengajaran dan pembelajaran dalam kajian ini masih terikat dengan pengamalan cara tradisional. Bagi murid berpencapaian rendah teknik sumbang saran ini masih memerlukan kebergantungan guru sepenuhnya yang di penghujungnya guru yang akan memberi segala input bagi membina karangan berkenaan.

Secara kesimpulannya, terdapat pelbagai kajian berkaitan kaedah atau teknik pengajaran karangan yang telah diuji dan menunjukkan keberjayaan kajian berkenaan. Kemampuan sesebuah teknik atau kaedah yang diperkenalkan itu bergantung kepada faktor tahap pencapaian murid yang pelbagai. Terdapat beberapa kajian yang tidak sesuai diaplikasikan kepada murid lemah kerana cara pelaksanaan teknik berkenaan memerlukan tahap pemikiran yang tinggi dan perlu diselesaikan dalam satu-satu tempoh pengajaran dan pembelajaran.

\section{KAEDAH KAJIAN}

Kajian ini merupakan sebuah kajian kuantitatif yang memilih sampel secara rawak. Kajian kuasi eksperimen ini melibatkan 50 orang murid menjadi sampel dan dibahagikan kepada dua kumpulan iaitu, kumpulan rawatan dan kumpulan kawalan. Sampel yang dipilih ini adalah berdasarkan tahap pancapaian pelajar berkenaan iaitu, pelajar yang berpencapaian sederhana. Kumpulan rawatan dan kumpulan kawalan dipilih daripada sekolah yang berbeza kerana mahu mengambil sampel yang mempunyai latar belakang pencapaian yang sama. Hal ini kerana sukar untuk mencari dua buah kelas yang mempunyai tahap pencapaian yang sama dalam satu tingkatan dan di sekolah yang sama.

Setiap sampel bagi kedua-dua kumpulan ini manjalani ujian pra. Instrumen bagi ujian pra ini diambil daripada soalan peperiksaam Sijil Pelajaran Malaysia (SPM) Bahasa Melayu Kertas 1. Justifikasi pemilihan soalan SPM ini diambil kerana bentuk dan aras soalan yang diperakui dan diguna pakai diperingkat kebangsaan. Setelah menjalani ujian pra, kumpulan rawatan akan menjalani tujuh sesi pengajaran bersama. Bagi kumpulan kawalan sesi pengajaran biasa juga dijalankan selama tujuh kali. Data berikutnya yang diambil ialah data ujian pasca. Instrumen bagi ujian pasca ini sama seperti ujian pra.

Data yang digunakan dalam kajian ini ialah markah pemeriksaan karangan iaitu daripada markah satu sehingga markah 100. Oleh hal yang demikian, skala min yang akan diperoleh dalam analisis data menunjukkan bilangan atau digit yang besar kerana data yang digunakan ialah markah ujian karangan. Markah ujian pra dan pasca antara kedua-dua kumpulan ini dianalisis dan dibandingkan bagi melihat kesan pengajaran bersama terhadap pencapaian penulisan karangan murid.

Dapatan yang diperoleh daripada kajian ini dianalisis menggunakan SPSS. Data ujian yang diperoleh dianalisis bagi menilai data dari segi nilai minimum dan maksimum, min dan sisihan piawai.

\section{DAPATAN KAJIAN}

Dapatan kajian ini akan dihurai berpandukan objektif kajian yang telah ditetapkan. Objektif kajian ini iaitu, mengenal pasti kesan penggunaan kaedah pengajaran bersama terhadap pencapaian murid dalam penulisan karangan Bahasa Melayu. Oleh itu kajian ini menunjukkan dua perkara iaitu, perbezaan pencapaian penulisan karangan bagi murid kumpulan rawatan sebelum dan selepas menjalani tujuh sesi pengajaran dan pembelajaran menggunakan kaedah pengajaran bersama dan perbandingan markah antara kumpulan rawatan dan kumpulan kawalan. 
JADUAL 1 Perbezaan Min Markah Ujian Pra bagi Kumpulan Rawatan dan Kumpulan Kawalan

\begin{tabular}{lccccc}
\hline & $\begin{array}{c}\text { Bil. } \\
\text { Sampel }\end{array}$ & Minimum & Maksimum & Min & Sisihan Piawai \\
\hline Ujian Pra Kumpulan_Rawatan & 25 & 35.00 & 80.00 & 63.3200 & 14.99644 \\
\hline Ujian Pra Kump. Kawalan & 25 & 35.00 & 85.00 & 64.1200 & 14.48655 \\
\hline Bil. Sampel & 25 & & & & \\
\hline
\end{tabular}

Jadual 1 menunjukkan perbezaan min ujian Pra antara kumpulan rawatan dan kumpulan kawalan. Kedua-dua kumpulan ini menunjukkan nilai minimum markah ujian yang sama iaitu, 35 manakala markah maksimum 80 markah bagi kumpulan rawatan dan 85 markah kumpulan kawalan. Nilai bagi Min pula menunjukkan markah ujian Pra bagi kumpulan kawalan lebih tinggi iaitu 64 berbanding 63 bagi kumpulan rawatan. Perbezaan markah ini menunjukkan pencapaian awal murid dalam penulisan karangan sebelum menjalani tujuh kali sesi pengajaran. Markah minimum dan maksimum yang ditunjukkan menggambarkan bahawa tahap pencapaian kedua-dua kumpulan ini hampir sama sebelum menjalani tujuh kali sesi pengajaran yang telah ditetapkan. Nilai Min yang berbeza menunjukkan terdapat perbezaan markah ujian pra antara kumpulan rawatan dan kumpulan kawalan. Oleh itu, analisis dapatan ini menolak hipotesis yang pertama iaitu tidak terdapat perbezaan markah antara kumpulan rawatan dan kumpulan kawalan. Dalam kajian ini, terdapat perbezaan markah namun perbezaan berkenaan tidak menunjukkan beza markah yang besar.

JADUAL 2 Perbezaan Min Markah Ujian Pasca bagi Kumpulan Rawatan dan Kumpulan Kawalan

\begin{tabular}{lccccc}
\hline & $\begin{array}{c}\text { Bil. } \\
\text { Sampel }\end{array}$ & Minimum & Maksimum & Min & Sisihan Piawai \\
\hline $\begin{array}{l}\text { Ujian Pasca } \\
\text { Kumpulan_Rawatan }\end{array}$ & 25 & 40.00 & 87.00 & 68.4400 & 15.00022 \\
\hline $\begin{array}{l}\text { Ujian Pasca } \\
\text { Kump. Kawalan }\end{array}$ & 25 & 36.00 & 89.00 & 66.4400 & 14.88030 \\
\hline Bil. Sampel & 25 & & & & \\
\hline
\end{tabular}

Jadual 2 menunjukkan perbezaan Min bagi ujian Pasca bagi kedua-dua kumpulan iaitu, Kumpulan Rawatan dan Kumpulan Kawalan. Bagi nilai markah minimum, Kumpulan Rawatan menunjukkan nilai markah 40 lebih tinggi daripada Kumpulan Rawatan iaitu hanya sebanyak 36 markah. Walau bagaimanapun nilai maksimum pula menunjukkan Kumpulan Kawalan lebih tinggi daripada kumpulan Rawatan iaitu sebanyak 89 markah berbanding 87 markah. Purata markah iaitu nilai min bagi kedua-dua kumpulan menunjukkan Kumpulan Rawatan lebih tinggi berbanding Kumpulan Kawalan iaitu sebanyak 68 markah. Setelah menjalani tujuh kali sesi pengajaran, data menunjukkan min bagi kumpulan rawatan lebih tinggi berbanding kumpulan kawalan. Perbezaan ini menunjukkan murid di dalam kumpulan rawatan yang menjalani tujuh kali sesi pengajaran bersama menerima atau memberi kesan positif terhadap pengajaran bersama yang dijalani. Nilai min yang ditunjukkan terdapat perbezaan markah ujian pasca antara kumpulan rawatan dan kumpulan kawalan. Dapatan analisis ini juga menolak hopitesis yang kedua iaitu tidak terdapat perbezaan markah dalam ujian pasca antara kumpulan rawatan dan kumpulan kawalan. Hal ini menunjukkan, walaupun perbezaan markah yang tidak ketara, namun perbezaan markah yang ditunjukkan menggambarkan kaedah pengajaran bersama ini mampu meningkatkan pencapaian murid. Nilai purata iaitu min kumpulan rawatan yang lebih tinggi menunjukkan purata pencapaian keseluruhan murid kumpulan rawatan lebih baik berbanding kumpulan kawalan. 


\section{IMPLIKASI DAN CADANGAN}

Kajian ini memberi implikasi yang baik kepada guru dan juga murid dalam menilai kaedah yang berkesan untuk menjalankan pengajaran karangan. Kaedah pengajaran bersama yang digunakan ini menunjukkan terdapat perbezaan markah ujian yang dicatatkan antara kumpulan rawatan dan kumpulan kawalan. Perbezaan ini juga menunjukkan markah kumpulan rawatan yang menjalani kaedah pengajaran bersama lebih daik daripada kumpulan kawalan yang menggunakan kaedah pengajaran tradisional. Penemuan berkenaan kaedah yang lebih sesuai untuk menjagar karangan adalah sangat penting kerana dapat meningkatkan lagi pencapaian pelajar selain inovasi dalam cara pengajaran guru di sekolah.

Cadangan kajian lanjutan yang boleh dilakukan berpandukan kajian ini adalah dengan meneliti sama ada kaedah ini berkesan untuk murid antara jantina sama ada lelaki atau perempuan. Berkemungkinan kaedah ini hanya bersesuaian untuk murid lelaki namun tidak sesuai untuk murid perempuan. Selain itu, kajian yang lebih mendalam juga boleh dilakukan terhadap aras murid. Persoalan yang boleh dikaji adalah sama ada kaedah pengajara bersama ini benar-benar sesuai dengan murid berpencapaian lemah ataupun murid yang berpencapaian cemerlang. Hal ini demikian kerana, faktor yang dinyatakan ini dilihat akan mempengaruhi keputusan pencapaian ujian yang dijalankan.

\section{KESIMPULAN}

Kajian yang telah dijalankan ini menunjukkan bahawa murid dapat menerima kaedah pengajaran bersama dengan baik kerana mencatat keputusan ujian pasca yang lebih tinggi. Peningkatan ini menjadi kayu ukur kepada perubahan kaedah pengajaran yang perlu dilakukan demi mencapai objektif yang diharapkan. Kaedah ini juga memberi para guru ruang yang lebih besar dalam merangka dan melaksanakan pengajaran dan pembelajaran yang lebih berkesan selain memberi ruang kepada murid untuk belajar dengan lebih baik.

\section{RUJUKAN}

Goldwriter yang diedit oleh Linda M. Rhinehart Neas. (2012). Co-teaching and different styles of co-teaching. http://brightubeducation.com/special-ed-inclusion-strategies/4096

Indah Eyah Abu Samah. (2012). Menilai keberkesanan teknik sumbang saran terhadap pencapaian kemahiran menulis karangan murid tingkatan empat. Tesis Sarjana yang tidak diterbitkan. Universiti Putra Malaysia.

Lembaga Peperiksaan Malaysia SPM. (2015). Bahasa Melayu Kertas 1.

Mariam Md. Saad. (2011). Pengajaran kemahiran penulisan karangan naratif bahasa Melayu menggunakan kaedah kata tanya. Tesis Sarjana yang tidak diterbitkan, Universiti Pendidikan Sultan Idris.

Mohammed Aliakbari. (2009). Implementing a co-teaching model for improving EFL learners grammatical proficiency. International Conference ICT for Language Learning. $3^{\text {rd }}$ edition.

Parker, A. K. (2010). The impacts of co-teaching on the general education student. Tesis Doktor Falsafah yang tidak diterbitkan. Universiti of Central Florida Orlando, Florida.

Potter, S. K. (2011). Co-teaching as an effective approach to improving student result. Tesis Ijazah Sarjana Muda yang tidak diterbitkan. Iniversiti of Central Missouri.

Rozita Radhiah Said \& Abdul Rashid Jamian. (2012). Amalan pengajaran karangan guru cemerlang di dalam bilik darjah: kajian satu kes pembagai lokasi. Asia Pasific Journal of Educators and Education, Vol. 27, 57-68, 2012.

Shahlan Surat, Shalinawati Ramli. \& Semah Rahman. (2013). Sumbangan elemen metakofnitif terhadap pencapaian penulisan karangan. Jurnal Pendidikan Bahasa Melayu MyLEJ, Vol. 3, Bil. 2 (Nov. 2013): 79-91

Tuan Jah Tuan Yusof \& Faridah Nazir. (2011). Pengajaran kemahiran bahasa Melayu. Puchong: Penerbit Multimedia.

Tuan Jah Tuan Yusof. (2011). Kaedah pengajaran bahasa Melayu sekolah rendah. Puchong: Penerbit Multimedia.

Villa, R. A., Thausand, J. S., \& Nevin, A. I. (2004). A guide to co-teaching: practical tips for facilitating student learning. California: Corwin Press.

Yusfaiza Yusuff \& Mohd Isha Awang. (2012). Aplikasi pembelajaran jigsaw II dalam pengajaran penulisan bahasa Melayu. Jurnal Pendidikan Bahasa Melayu-JPBM, ISSN: 2180-4842, Vol. 2, Bil. 2 (Nov.2012): 62-70. 